\title{
Ольга Каламан
}

\section{ШЛЯХИ ПІДВИЩЕННЯ КОНКУРЕНТОСПРОМОЖНОСТІ ПІДРИЕМСТВ МАЛОГО ТА СЕРЕДНЬОГО БІЗНЕСУ ВИНОРОБНОЇ ГАЛУЗІ}

\author{
Ольга Каламан
ПУТИ ПОВЫШЕНИЯ КОНКУРЕНТОСПОСОБНОСТИ ПРЕДПРИЯТИЙ МАЛОГО И СРЕДНЕГО БИЗНЕСА ВИНОДЕЛЬЧЕСКОЙ ОТРАСЛИ

\author{
Olga Kalaman
WAYS TO INCREASE COMPETITIVENESS OF SMALL AND MEDIUM-SIZED ENTERPRISES OF WINEMAKING INDUSTRY

У статті розглянуто актуальність дослідження терміна «конкурениіяа», проаналізовано недоліки основної частини існуючих визначень поняття «конкурентоспроможність підприємства» та запропоноване його альтернативне формулювання. Доведена важливість та вагомість державної підтримки в розвитку конкурентоспроможного малого та середнього підприємництва. Наведено приклади державного регулювання малого та середнього підприємництва в провідних країнах світу. Проаналізовано основні показники діяльності суб'єктів малого та середнього підприємництва та кількість малих підприсмств України за останні роки. Показана питома вага малих та середніх підприємств у загальній кількості існуючих підприємств Украӥни. Виявлено, шо для Одеської області актуальним є розвиток виноробних підприємств малого та середнього бізнесу. Доведено, щзо на ринку виноградарства й виноробства Одеського регіону можна констатувати підвищення конкурентоспроможності діяльності малих та середніх підприємств виноградарської галузі. Проте діяльність виноробних підприємств залежить від державної політики в иій сфері, що не повною мірою використовують і можливості самих фірм щодо підвищення впізнаваності, підвищення купівельної прихильності й лояльності, розширення ринків збуту.

Ключові слова: конкуренція; конкурентоспроможність; конкурентний потенціал підприємства; мале та середнє підприємниитво; держсавне регулювання; виноробні підприємства.

Рис.: 2. Табл.: 3. Бібл.: 17.

В статье рассмотрены актуальность исследования срока конкуренция, проанализированы недостатки основной части существующих определений понятия «конкурентоспособность предприятия» и предложено его альтернативное формулировки. Доказана важность и значимость государственной поддержки в развитии конкурентоспособного малого и среднего предпринимательства. Приведены примеры государственного регулирования малого и среднего предпринимательства в ведущих странах мира. Проанализированы основные показатели деятельности субъектов малого и среднего предпринимательства и количество малых предприятий Украины за последние годы. Показана удельный вес мальхх и средних предприятий в общем количестве существующих предприятий Украины. Выявлено, что для Одесской области актуальным является развитие винодельческих предприятий малого и среднего бизнеса. Доказано, что на рынке виноградарства и виноделия Одесского региона можно констатировать повышение конкурентоспособности деятельности мальхх и средних предприятий виноградарской отрасли. Однако деятельность винодельческих предприятий зависит от государственной политики в этой сфере, в полной мере не используется и возможности самих фирм по повышению узнаваемости, повышение покупательной приверженности и лояльности, расширение рынков сбыта.

Ключевые слова: конкуренция; конкурентоспособность; конкурентный потенциал предприятия; малое и среднее предпринимательство; государственное регулирование; винодельческие предприятия.

Рис.: 2. Табл.: 3. Библ.: 17.

The article examines the relevance of the research on the term competition, analyzes the shortcomings of the main part of the existing definitions of the concept of "enterprise competitiveness" and proposes its alternative formulation. The importance and importance of state support in the development of competitive small and medium entrepreneurship has been proved. The examples of state regulation of small and medium business in the leading countries of the world are given. The main indicators of the activity of small and medium-sized enterprises and the number of small enterprises of Ukraine in recent years are analyzed. The share of small and medium-sized enterprises in the total number of existing Ukrainian enterprises is shown. It is revealed that the development of small and medium-sized wineries in the Odessa region is relevant. It is proved that on the market of viticulture and winemaking of the Odessa region it is possible to state increase of competitiveness of activity of small and medium enterprises of the viticultural branch. However, the activities of wineries depend on state policy in this area, which is not fully exploited and the ability of the firms themselves to increase awareness, increase customer loyalty and loyalty, expand markets.

Keywords: competition; competitiveness; competitive potential of the enterprise; small and medium-sized enterprises; state regulation; winemaking enterprises.

Fig.: 2. Table: 3. References: 17.

JEL Classification: D41; G28; L28; Q19

Постановка проблеми. Конкуренція і конкурентоспроможність посідають центральне місце в сучасній теорії і практиці стратегічного управління. Конкуренція як явище і як економічна категорія являє собою об'єкт пильної уваги дослідників протягом біль-

(C) Каламан О. Б., 2019 
ФІНАНСОВІ РЕСУРСИ: ПРОБЛЕМИ ФОРМУВАННЯ ТА ВИКОРИСТАННЯ

ше ніж 200 років. Її проблемами займалися багато видатних економістів, у результаті чого в науці склалися три основні підходи до вивчення конкуренції, кожен з яких вважається самодостатнім. Спочатку в працях А. Сміта і Д. Рікардо, пізніше в роботах А. Курно, У. Джевонса, Дж. Б. Кларка, А. Маршалла, Ф. Найта та ін. Конкуренція трактувалася в межахз поведінкового підходу як сила, яка характеризує взаємодію попиту і пропозиції, що забезпечує функціонування ринкового механізму ціноутворення і регулювання пропорцій суспільного виробництва.

Аналіз останніх досліджень і публікацій. Дослідження конкурентоспроможності підприємств, пропоноване в економічній літературі авторами А. Вороновим, А. Дементьєвою, І. Максимовим, М. Мельниковою, А. Семененко, С. Цвєтковою та ін., дозволяє дійти висновку про те, що найчастіше поняття «конкурентоспроможність підприємства» зводять до «...здатності підприємства виробляти конкурентоспроможний товар» [2]. Дослідження конкурентоспроможності галузі здебільшого грунтуються на визначенні М. Портера, який орієнтується на виділення критеріїв оцінки рівня конкурентоспроможності в системі світової економіки. У зв'язку з відсутністю чіткого поняття досить часто за конкурентоспроможність галузі видають або «спеціалізацію галузі» (в тому числі міжнародну), або «домінуючі галузі» (що займають високу питому вагу в структурі економіки) [1]. Водночас, на думку авторів В. Іванець, А. Резника, на світових ринках конкурують не галузі, а товари, що базуються на макротехнологіях (технологіях, що дозволяють виробляти великі виробничі вироби, які характеризуються великою капіталоємністю, яка визначається, у свою чергу, наукоємністю і матеріаломісткістю) [5].

Виділення недосліджених частин загальної проблеми. Різноманітність методологічних підходів до визначення конкурентоспроможності підприємства не дозволяє встановити сутність цього поняття, склад його змістоутворюючих елементів, які необхідні для розробки методів оцінки конкурентоспроможності підприємства і прийняття управлінських рішень щодо моделювання ії рівня. Різне розуміння того ж самого явища суб'єктами ринку при спільній діяльності може перешкоджати узгодженню їхніх дій. Нині відсутні загальноприйняте трактування методів оцінки конкурентоспроможності, що задовольняє всіх суб'єктів ринку не тільки підприємств, а й інших об'єктів (товарів, послуг, галузей, регіонів, країн). Оцінка конкурентоспроможності - суб'єктивний процес, і що розуміє під цією категорією особа, яка приймає рішення, який при цьому вибере метод оцінки іiі рівня, такий і може отримати результат.

При сьогоднішній плутанині у сфері виміру конкурентоспроможності різних об'єктів різними дослідниками можуть бути отримані абсолютно протилежні результати щодо тих самих об'єктів. Це пояснюється тим, що конкуренція і все, що пов'язано 3 нею, для господарюючих суб'єктів України порівняно нове та маловивчене явище, тому проявляються наслідки «хвороби росту», що є цілком об'єктивно.

За радянських часів конкуренція була пригнічена планом, економіка була позбавлена однієї з найпотужніших творчих сил природи. В Україні назріла гостра потреба в розвитку конкуренції, вдосконалення методів оцінки й управління конкурентоспроможністю різних об'єктів. Важко керувати тим об'єктом, сутність якого не виявлено, тому необхідно внести ясність у понятійний апарат у цій сфері.

Мета цієї статті полягає в проведенні аналізу існуючих визначень конкурентоспроможності підприємства й формулюванні визначення, що враховує виявлені недоліки; дослідженні успішного досвіду у сфері регулювання діяльності підприємств середнього та малого бізнесу в провідних країнах світу; аналізі результативності діяльності середніх та малих підприємств України, зокрема у сфері виноробної галузі.

Виклад основного матеріалу. Порівняльний аналіз відомих визначень поняття «конкурентоспроможність підприємства» дозволяє зробити такі висновки: 
ФІНАНСОВІ РЕСУРСИ: ПРОБЛЕМИ ФОРМУВАННЯ ТА ВИКОРИСТАННЯ

1. Усю сукупність визначень можна поділити на три групи:

а) характеризує внутрішню і зовнішню діяльності фірми, без згадки товару;

б) грунтується тільки на товарній складовій конкурентоспроможності;

в) поєднує товар і виробничу діяльність суб'єкта.

Відповідно до Закону України «Про захист економічної конкуренції» ця категорія характеризує змагання між суб'єктами господарювання з метою здобуття завдяки власним досягненням переваг над іншими суб'єктами господарювання, внаслідок чого споживачі, суб'єкти господарювання мають можливість вибирати між кількома продавцями, покупцями, а окремий суб'єкт господарювання не може визначати умови обороту товарів на ринку [11].

Ключові елементи конкурентоспроможності на рівні підприємства - це «товар», «ринок». За рідкісним винятком без оцінки позиції товару на ринку не можна вести мову про конкурентоспроможність його виробника. Виняток становлять випадки, коли товари конкуруючих підприємств за ціною і якістю абсолютно однакові, що трапляється дуже рідко. Наприклад, електроенергія, що генерується різними компаніями, якщо ціна на неї встановлена для всіх директивно на одному рівні. Тоді конкурентоспроможність підприємства тотожна його конкурентному потенціалу. На ринку також результат діяльності фірми - це його товар, конкурентоспроможність якого оцінює ринок. Тандем «результат - його автор» повинен розглядатися спільно. За конкурентоспроможним товаром на ринку може стояти підприємство, що «розвалюється», і навпаки. Однозначно можна сказати, якщо підприємство йде на спад, то в майбутньому в нього навряд чи будуть конкурентоспроможні товари. Це твердження більше відноситься до виробників наукомісткої, високотехнологічної, технічно складної продукції.

Конкурентоспроможності виробників простих дешевих товарів, які не потребують великих зусиль на розробку, може ототожнюватися 3 конкурентоспроможністю його товарів, тобто їхньою ринковою позицією. Боротьба на товарних ринках між виробниками за споживача $є$ безперервним процесом, тому при оцінці конкурентоспроможності підприємств конкурентоспроможність товару повинна розглядатися спільно з конкурентним потенціалом підприємства.

2. Лише одне визначення з існуючих містить слово «перевага». Конкуренція - це змагання фірм на конкретних сегментах ринку за обмежений обсяг платоспроможного попиту, отже, повинні бути переможці змагання. Конкурентоспроможність порівняльна категорія, тобто повинен застосовуватися математичний апарат оцінки й ранжирування порівнюваних об'єктів. Хтось повинен бути краще, хтось гірше, тобто переможець повинен переважати суперників.

3. Відомі визначення однозначно не встановлюють склад змістоутворюючих елементів терміна «конкурентоспроможність підприємства», що перешкоджає виробленню методу вимірювання її рівня. Відомо, що не можна виміряти, тим не можна управляти. Визначення повинно вказати напрям для розробки методу оцінки конкурентоспроможності підприємства. Воно має поєднувати сутнісні та змістовні елементи економічної дисципліни - маркетингу й технічної дисципліни - кваліметрії. Конкурентоспроможність - явище динамічне, вона повинна оцінюватися за станом на конкретний момент часу й незалежно від конкурентів, тобто індивідуально. На ці обставини у відомих визначеннях не приділено достатньої уваги.

4. Наведені визначення не орієнтовані на вирішення управлінських завдань. Менеджерів насамперед цікавить проблема управління рівнем конкурентоспроможності підприємства. Порівнюючи результати оцінювання конкурентів за тією ж самою методикою, можна їх ранжувати за конкурентоспроможністю, простежити динаміку рівня конкурентоспроможності досліджуваних об’єктів. Вимірювання конкурентоспроможності підпри- 
ФІНАНСОВІ РЕСУРСИ: ПРОБЛЕМИ ФОРМУВАННЯ ТА ВИКОРИСТАННЯ

ємств створює можливість моделювати іiі рівень, виробити обгрунтовані управлінські рішення. Рівень конкурентоспроможності підприємства піддається управлінню та здійснюється цілеспрямованим впливом на показники як товару, так і самого підприємства.

5. У жодному відомому визначенні не вказано, хто ж оцінює конкурентоспроможність підприємства. Однозначно, що для зовнішнього користування вона повинна оцінюватися суб'єктами зовнішнього середовища. Для управлінських цілей фірма сама повинна оцінити рівень своєї конкурентоспроможності, але за тією ж методикою, за якою її оцінюють інші суб'єкти.

6. У відомих визначеннях не зазначено часового чинника конкурентоспроможності. Конкуренція на ринку - процес безперервний, тому «переможець» у конкурентній боротьбі визначається на конкретний момент часу. На кожен момент часу може бути складений ранг конкурентоспроможності підприємств, і він $є$ динамічний.

7. Деякі відомі визначення підкреслюють, що конкурентоспроможність підприємства встановлюється на певному ринку. Підприємство, по-перше, не може одночасно бути присутнім на всіх ринках, по-друге, воно може бути конкурентоспроможним на одних і неконкурентоспроможним на інших ринках. Навіть на одному і тому ж ринку, на різних сегментах конкурентні позиції підприємства можуть істотно відрізнятися. У визначенні повинно бути вказано, на яких ринках підприємство $є$ конкурентоспроможним, а точніше, на яких сегментах ринку.

8. В існуючих визначеннях, якщо навіть згадується товар, не проводиться його конкретизація. Конкурентоспроможність підприємства доцільно оцінити щодо конкретного товару. Не виключається, що в того ж самого виробника можуть бути одні товари конкурентоспроможні, а інші - ні. Отже, підприємство може конкурентоспроможним за одним товаром, але неконкурентоспроможним за іншим. Для фірм, які виробляють широку номенклатуру продукції, правильніше було б вести мову про конкурентоспроможність за конкретним товаром на обраному сегменті ринку.

9. Наявні визначення частіше орієнтовані на оцінку конкурентоспроможності підприємств на поточний момент, за фактичними даними, тоді як для управлінських цілей важливіше орієнтація на майбутнє, врахування потенціалу зростання.

10. У жодному відомому визначенні не згадується про те, що конкурентоспроможність повинна бути досягнута без шкоди для оточення. Підприємство може підвищити свою конкурентоспроможність і не продуктивними шляхом, наприклад, ухиленням від податків, економлячи кошти на природоохоронних заходах, знижуючи заробітну плату працівникам тощо. Конкурентоспроможність, досягнута зі шкодою зовнішньому і внутрішньому середовищу є недовготривалою. Причому згадані категорії можуть вимірюватися індивідуально. У цьому випадку оцінюються і порівнюються показники того самого підприємства в різні періоди, виявляється напрям розвитку підприємства, проблемні сфери; конкурентоспроможність досягається без шкоди для оточення; визначення відкриває шлях для подальших досліджень у цій сфері.

Важливо зазначити, що проведений критичний огляд поняття «конкурентоспроможність підприємства» дозволив виявити недоліки відомих визначень. Конкурентоспроможність малих і середніх підприємств можна визначити як здатність підприємницьких структур проявляти гнучкість, адаптивність до постійних змін зовнішнього середовища 3 метою збільшення, зменшення, або збереження займаної частки ринку залежно від стратегії підприємства.

Аналіз світової практики показує, що сектор малих і середніх підприємств є основою створення і розвитку національної економіки, заснованої на знаннях. Малі та середні підприємства в розвинених країнах становлять найважливіший сектор національних економік. Якщо великі підприємства визначають рівень науково-технічного і виробни- 
чого потенціалу країни, то малі й середні підприємства, будучи найбільш масовою формою ділового життя, забезпечують соціально-економічну стабільність розвитку. За останніми даними, частка малих та середніх підприємств у ВВП у країнах Свросоюзу, США, Китаї на сьогодні перевищує 50 \%. Зайнято в малому й середньому підприємництві поки тільки чверть працюючих українців. До 2020 р. частка малого бізнесу у ВВП України повинна була становити 50 \%. У ньому має бути зайнято не менше ніж половини економічно активного населення країни.

Сучасне ринкове середовище динамічне й мінливе. Безперервно відбуваються зміни в смаках і запитах споживачів, нововведення в технологіях, управлінських методах. Усе це відкриває для малого і середнього бізнесу конкурентні переваги перед великими підприємствами, серед них найважливіші: оперативність реагування на зміни ринкової кон'юнктури, розписана як технологія моніторингу кон'юнктури відповідного сегмента ринку, ідентифікації потреби, трансформація виявленої потреби в проєкт, дизайн нового продукту або послуги ін.; низькі накладні витрати за рахунок функціонального використання всього персоналу малого підприємства на виробництво доданої вартості, що відносяться на собівартість продукції, що виробляється або надані послуги; орієнтація на постійну реалізацію можливостей оперативного оновлення технологій; сталість інноваційної поведінки як підвищення швидкості здійснення інновацій у всіх сферах діяльності малого підприємства (від виробленої продукції і послуг, що надаються до використання нових управлінських технологій, мотивації працівників тощо); пошук форм доступу до позикових фінансових ресурсів великих підприємств, прийняття на себе ризику здійсненності тих видів робіт, які економічно доцільно розвивати великому бізнесу; використання нових технологій маркетингових досліджень і активної реклами, доступної малому бізнесу.

Мале та середнє підприємництво найбільш ефективно реалізуються в країнах, де сильна ступінь лібералізації господарської діяльності поєднується з високою ефективністю державних інститутів, які активно підтримують підприємницькі організації. Так, аналізуючи вплив держави на малий бізнес у США, вітчизняні дослідники підкреслюють, що для регулювання його розвитку застосовувалися механізми, які відповідають завданням розвитку економіки. На першому етапі в середині XX ст. держава прагнула здебільшого розширити сегмент дрібного підприємництва, впроваджуючи цілий ряд програм сприяння підприємництву, зокрема: виділення позик, застосовуючи програми рівних кредитних можливостей, кредитні програми допомоги підприємницьким організаціям у разі крайньої потреби й ін. На наступному етапі, з кінця XX ст., пріоритетними завданнями держави щодо регулювання малого бізнесу стають розвиток соціальної сфери (Програма сприяння підприємствам малого бізнесу в мобілізації ресурсів для приведення своїх виробництв у відповідність 3 природоохоронними нормативами і стандартами), підтягування економіки відсталих регіонів (Програма сприяння малим підприємствам, що належать представникам національних меншин, а також аналогічні програми для жінок, ветеранів збройних сил), розширення галузевої структури малого бізнесу (Програма страхування будівельних підрядів для малого бізнесу) [8]. Механізмами державного регулювання малого та середнього підприємництва США є також державні гарантії по кредитах, укладання державних контрактів і субконтрактів, резервування прав на придбання ресурсів із федеральної власності, надання широкого спектра послуг, технічної, організаційної, управлінської допомоги. Починаючи з 90-х років $\mathrm{XX}$ ст. на передній план вийшло завдання стимулювання інноваційної діяльності господарюючих суб'єктів. Ця проблема в США вирішувалася на комплексній основі: створювалася відповідна правова база (Закони «Бей-Доула», «Стівенсона-Уайдлера», що забезпечили можливості використання наукових продуктів приватними підприємствами), розвивалася інституціональна структура (створювалися спільні започаткування бізнесу, держави, університетів, лабораторій , некомерційних організацій та ін.) [6]. 
ФІНАНСОВІ РЕСУРСИ: ПРОБЛЕМИ ФОРМУВАННЯ ТА ВИКОРИСТАННЯ

Державна стратегія регулювання малого підприємництва в Японії формувалася із середини XX ст. У 1963 році був прийнятий Основний закон про мале та середнє підприємництво, згідно з яким держава зобов'язана забезпечувати рівні умови для їхнього розвитку в конкурентному середовищі. Основні напрями регулювання малого та середньо підприємництва, передбачені цим законом включають цілі державного регулювання в частині модернізації обладнання, підвищення техніко-технологічного рівня; раціоналізації управління; забезпечення гарантій, а також проведення заходів щодо впорядкування субпідрядних відносин; щодо оптимізації розмірів малого та середньо підприємництва; збільшення експорту й розширення попиту; регулювання трудових відносин у підприємницькій сфері. Сучасна стратегія державного регулювання малого та середньо підприємництва в Японії грунтується на пріоритеті його розвитку в науково-технічному напрямі, але відрізняється диференційованим підходом щодо підприємств 3 різною чисельністю зайнятих. Для підприємств сімейного типу (до трьох осіб) використовується зміцнення і розвиток партнерських відносин на основі підрядів із великими фірмами, зацікавленими у високій кваліфікації працівників малого та середнього підприємництва для виконання замовлень продукції малими партіями (зазвичай це не машини, а спеціалізовані інструменти). Для підприємств від 4 до 9 осіб - розвиток субпідрядних відносин на основі унікальних ноу-хау, що забезпечують конкурентні переваги в собівартості, як і терміни поставки замовлень стандартної продукції. Для підприємств 3 кількістю зайнятих 10-29 осіб визначальним напрямом $є$ розвиток спеціалізації, що дозволяє зайняти певну нішу на ринку стандартизованої продукції. Для підприємств із 30-49 працівниками передбачено розвиток як субпідрядних відносин, так і підтримка самостійного функціонування на ринку високотехнологічної продукції на базі вдосконалення унікальної технології. Для підприємств із чисельністю працівників понад 50 осіб в Японії підтримується диверсифікація інноваційної діяльності та проведення НДДКР: спеціалізації тільки на НДДКР з подальшим продажом розробок; сприяння організації власного виробництва на основі результатів НДДКР фірми; сприяння розвитку повного циклу-НІОКР, виробництво, реалізація та експлуатація. У результаті такої стратегії регулювання малого підприємництва державою чисельність малого та середньо підприємництва провідних НДДКР в Японії наближається до 40 \% їх загальної кількості [7]. Ще однією особливістю розвитку малого та середньо підприємництва в Японії є спільне співіснування великих і дрібних компаній у більшості галузей: будівництво, транспорт, промисловості. Високо розвинений аутсорсинг [9].

Регулювання малого підприємництва диференційовано і по регіонах: в історичних центрах, наприклад, префектура Кіото, активно підтримує розвиток малого та середньо підприємництва у сфері туризму, екологічного спрямування (зокрема, переробка вторинної сировини), харчової галузі [10].

Характерною рисою державного регулювання малого підприємництва в країнах членах $\mathrm{CC} є$ наявність розвиненої системи спеціалізованих установ із державним або змішаним капіталом, участь різних організацій і відомств, множинність каналів отримання підприємцями допомоги, відсутність монополізму будь-якого одного державного органу, наявність структур, які б виробляли національну політику в даній області, механізми її реалізації, загальну стратегію, законодавче забезпечення, що здійснює координуючу функцію у вирішенні цього найважливішого соціально-економічного завдання.

Досвід Фінляндії цікавий тим, що вона регулює розвиток малого та середньо підприємництва саме як розвиток інноваційної основи сучасної економіки. У країні створена комплексна система державної, громадської та приватної підтримки підприємництва. Основними механізмами регулювання виступає мікрокредитування, венчурне фінансування, державні гарантії, створення бізнес-інкубаторів на базі цілих сіл і малих міст [13]. 
ФІНАНСОВІ РЕСУРСИ: ПРОБЛЕМИ ФОРМУВАННЯ ТА ВИКОРИСТАННЯ

Сьогодні позиції України щодо розвитку середніх та малих підприємств досить успішні. Уже розроблено та впроваджено в дію значна кількість нормативно-правових документів. Зокрема діє «Стратегія розвитку малого і середнього підприємництва в Україні на період до 2020 року» затверджена розпорядженням Кабінету Міністрів України від 24 травня 2017 р. № 504-p. [12]. Ї̈̈ основною метою є «сприяння розвитку підприємництва в Україні, створення сприятливих умов для відкриття, ведення і зростання малого і середнього підприємництва шляхом консолідації зусиль усіх заінтересованих сторін, що забезпечить соціально-економічний розвиток країни та підвищить рівень життя населення» [12]. В Україні становлення і розвиток малого підприємництва належить до найбільш значущих напрямів політики органів державної влади. Особливо значущим є той факт, що дійсно в період з 2016 року по 2018 рік кількість підприємств малого та середнього бізнесу в Україні дійсно зростала, про що свідчать дані табл. 1.

Таблиця 1

Основні показники діяльності суб'єктів малого та середнього підприємництва України на 2016-2018 рр.

\begin{tabular}{|c|c|c|c|c|c|c|}
\hline \multirow{2}{*}{ Показник } & \multicolumn{2}{|c|}{ Середні та малі підприємства разом } & \multicolumn{3}{|c|}{ 3 них мікропідприємства } \\
\cline { 2 - 7 } & 2016 & 2017 & 2018 & 2016 & 2017 & 2018 \\
\hline $\begin{array}{c}\text { Кількість підприємств, оди- } \\
\text { ниць }\end{array}$ & 305986 & 337857 & 355431 & 247695 & 278102 & 292772 \\
\hline $\begin{array}{c}\text { Середня чисельність праців- } \\
\text { ників, тис. осіб }\end{array}$ & 4214,5 & 4252,0 & 4385,2 & 642,7 & 714,6 & 704,3 \\
\hline $\begin{array}{c}\text { Кількість найманих працівни- } \\
\text { ків, тис. осіб }\end{array}$ & 4127,3 & 4153,7 & 4296,3 & 565,2 & 625,4 & 623,0 \\
\hline $\begin{array}{c}\text { Обсяг реалізованої продукції, } \\
\text { (товарів, послуг), млн грн }\end{array}$ & 3846080,9 & 4778418,6 & 5690210,0 & 361784,0 & 497777,1 & 599625,6 \\
\hline
\end{tabular}

Джерело: [4].

На рис. 1 наведено кількість малих підприємств України за 2016-2018 рр.

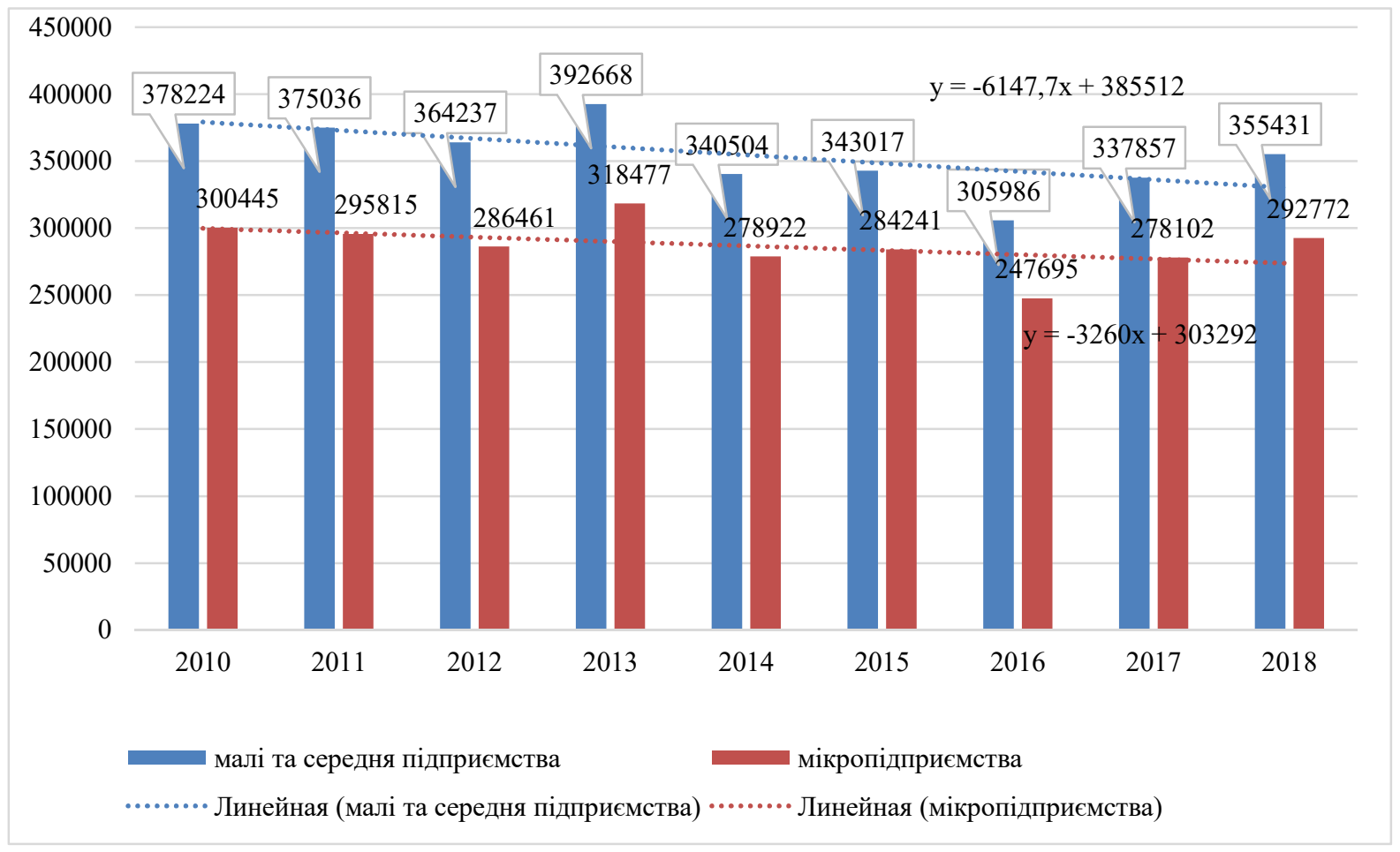

Рис. 1. Кількість малих і середніх підприємств та мікропідприємств за 2010-2018 рр. в Украӥні

Джерело: складено автором на основі джерела [4]. 
ФІНАНСОВІ РЕСУРСИ: ПРОБЛЕМИ ФОРМУВАННЯ ТА ВИКОРИСТАННЯ

Кількість малих та середніх підприємств (без мікропідприємств) на 1 січня 2019 року становить 16057 одиниць. Малі та середні підприємства країни переважно зайняті в переробній промисловості $(30,15$ \%) та сільському господарстві $(20,91 \%$ від загальної кількості підприємств). Проте варто зазначити, що саме вирощуванням винограду у 2018 році займалися 22 середні підприємства, 228 малих (серед них 205 мікропідприємств), а переробкою (тобто виробництвом виноградних вин) у 2018 році займалося 23 середні підприємства, 36 малих підприємств (зокрема 20 мікропідприємств) [4].

Така статистика свідчить про цікавий досвід підвищення конкурентоспроможної стратегії розвитку саме для підприємств виноградарсько-виноробної галузі як прикладу досягнення успішних позицій на вітчизняному та світовому ринку. Цікавим $\epsilon$ той факт, що саме малі підприємства у 2018 році становили більшу частину всіх підприємств за всіма видами діяльності - близько 90 \% (рис. 2).

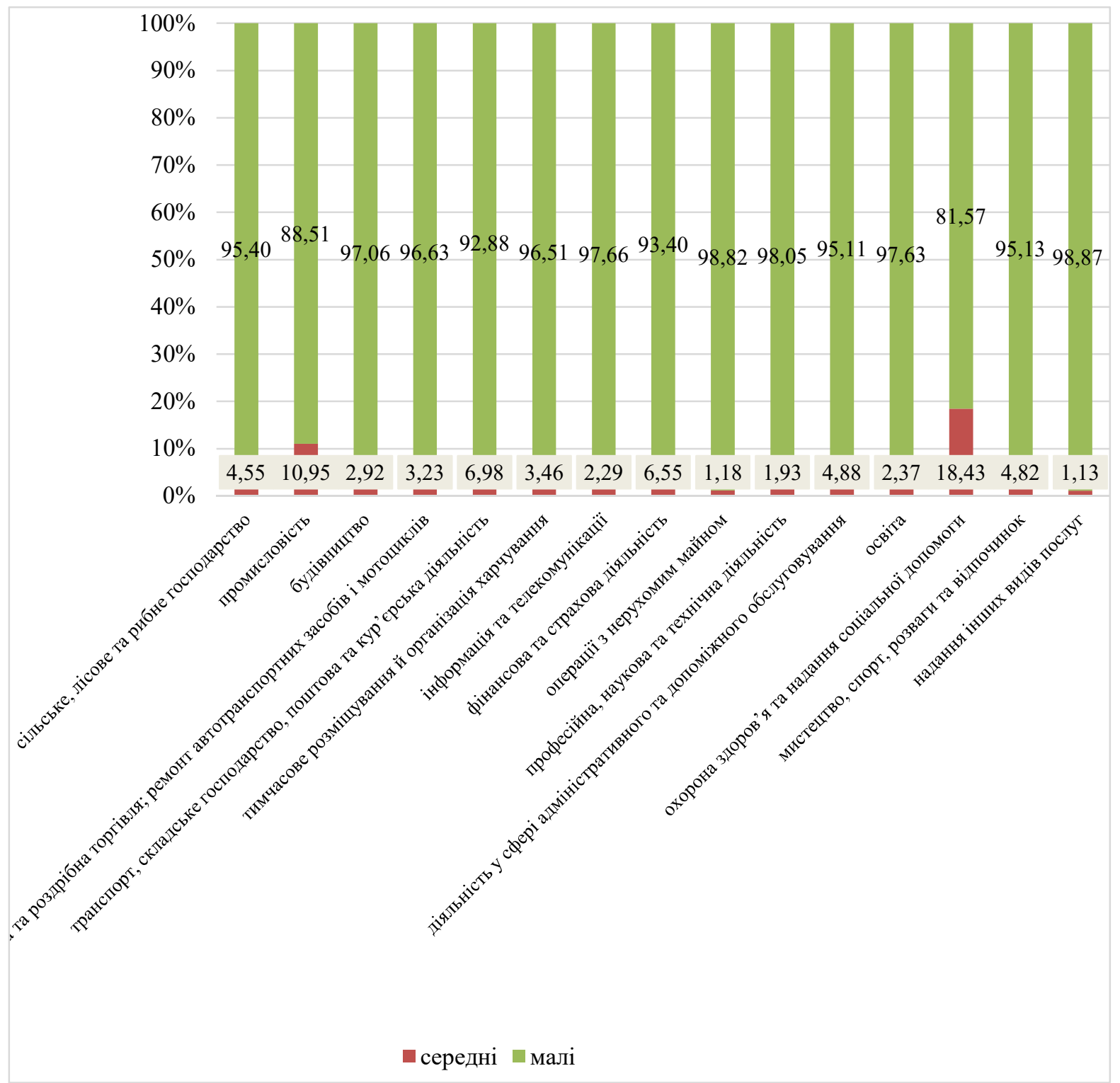

Рис. 2. Питома вага малих та середніх підприємств у загальній кількості існуючих підприємств у 2018 рочі в Украӥні

Джерело: складено автором на основі джерела [4]. 
ФІНАНСОВІ РЕСУРСИ: ПРОБЛЕМИ ФОРМУВАННЯ ТА ВИКОРИСТАННЯ

До основних труднощів у розвитку малого підприємництва можна віднести: недостатність заходів щодо розвитку інноваційної діяльності; низька якість виробленої продукції; нестача інвестицій; складність отримання площ для ведення господарської діяльності у зв'язку з високою орендною платою; складність доступу до ресурсів комерційних банків, недостатній розвиток системи мікрофінансування, нерозвинена система гарантій (поруки), слаборозвинені механізми самофінансування; низька ефективність діяльності галузевих асоціацій та об'єднань підприємців; нестача стартового капіталу та професійної підготовки для успішного початку підприємницької діяльності, а також коштів на розвиток підприємницької діяльності; недостатній професійний рівень підготовки і перепідготовки підприємців, нестача кваліфікованих фахівців; низький рівень інформаційного забезпечення підприємництва; часті зміни нормативноправової бази у сфері бізнесу; наявність адміністративних бар'єрів; недостатній маркетинг територій [3].

Аналіз розвитку малих підприємств в Україні говорить про наявність потенціалу його розвитку. Малі підприємства можуть стати одним із факторів, що забезпечує соціальну й політичну стабільність при ефективному регулюванні з боку держави. Від вибору пріоритетів розвитку економіки залежить ефективність соціально-економічних реформ у регіоні. Конкурентоспроможність будь-якого підприємства, зокрема середнього і малого, залежить від наявності та значущості його конкурентних переваг, завдяки яким забезпечуються фінансова, економічна і ринкова стійкість. Для суб'єктів малого інноваційного підприємництва базові конкурентні переваги визначаються знаннями і талантом працюючих там людей, їхньою здатністю і прагненням займатися дослідженнями, умінням не тільки генерувати бізнес-ідеї, а й комерціалізувати їх. Стратегічними конкурентними перевагами середніх і малих підприємств є їх гнучкість і мобільність, здатність швидко реагувати на зміни потреб ринку. Конкурентні переваги не довговічні, оскільки завдяки новим знанням та вмінням досить швидко ростуть нові конкуренти. Пізнання суті і прояви конкурентоспроможності малого підприємництва передбачає систематизацію та всебічне вивчення умов і факторів, що формують ії рівень. Основними проблемами, що гальмують розвиток малого і середнього підприємництва в Україні, є:

- слабка орієнтованість нормативно-правової бази на стимулювання розвитку малого та середнього підприємництва;

- недостатнє ресурсне забезпечення (фінансове, майнове й інформаційне) суб'єктів малого і середнього підприємництва та організацій інфраструктури підтримки малого і середнього підприємництва;

- недостатній доступ до стартового капіталу для підприємців-початківців;

- недостатній доступ до капіталу для реалізації перспективних проєктів розвитку підприємств;

- недостатньо розвинена система державної гарантійної підтримки суб'єктів малого та середнього підприємництва;

- дефіцит кваліфікованих кадрів, недостатній рівень професійної підготовки, недостатній освітній рівень керівників і фахівців, що працюють у суб'єктах малого і середнього підприємництва;

- низький рівень розвитку інфраструктури підтримки малого та середнього бізнесу в муніципальних районах України.

Вищевказані проблеми визначають необхідність і подальший розвиток основних напрямів державної підтримки малого та середнього підприємництва в Україні. Політика регіону в області малого і середнього підприємництва має бути спрямована на формування сприятливих умов для їхнього сталого розвитку. Ї̈̈ пріоритетними напрямами будуть: 
ФІНАНСОВІ РЕСУРСИ: ПРОБЛЕМИ ФОРМУВАННЯ ТА ВИКОРИСТАННЯ

1) вдосконалення нормативно-правової бази, що регулює розвиток державної підтримки малого та середнього підприємництва;

2) усунення адміністративних бар'єрів, що перешкоджають розвитку малого і середнього підприємництва в Україні;

3) посилення взаємодії виконавчих органів державної влади країни й органів місцевого самоврядування 3 підприємницькими структурами 3 метою розвитку державної підтримки малого та середнього підприємництва;

4) забезпечення більш високих темпів розвитку малого і середнього підприємництва в інноваційній сфері;

5) підвищення кваліфікації та перепідготовки осіб, зайнятих у сфері малого та середнього бізнесу;

6) залучення малих і середніх підприємств у зовнішньоекономічну діяльність, залучення зарубіжних інвестицій у сферу малого і середнього бізнесу;

7) розвиток інфраструктурної підтримки малого і середнього підприємництва.

Реалізація пріоритетних напрямів сприятиме сталому розвитку малого і середнього підприємництва в регіоні та підвищення якості життя населення країни. Отже, фактори, що впливають на конкурентоспроможність підприємств, відображають різні аспекти ринкової діяльності суб'єктів малого підприємництва, а також параметри, що відображають ступінь використання факторів виробництва.

На окрему увагу заслуговує досвід регулювання розвитку виноградарськовиноробних підприємств Одеського регіону. Одеський регіон має унікальні конкурентні переваги, а у підприємств області є сильні сторони, які дозволяють конкурувати й на світовому ринку. Історично виноградарство і виноробство в України не розглядалися як значущі з погляду розвитку країни, мали місцеве значення, були орієнтовані на валовий збір винограду і виробництво столових вин в основному на місцевий ринок. Водночас кліматичні умови Одеського регіону схожі з країнами - виробниками марочних вин, що мають широкі можливості для розвитку та підвищення конкурентоспроможності українського виноробства як на місцевому, так і на світовому рівні. Україна має у своєму розпорядженні сотні тисяч гектарів землі, придатних для виноградарства, однак сьогодні, їі немає в десятці країн, що лідирують у сфері виноградарства. За виробництвом вина Україну обганяє навіть Африка. Дані про динаміку й географію виробництва вина у 2018 році представлені в табл. 2.

Таблиця 2

Показники розвитку виноградарсько-виноробної галузі у світовому розрізі

\begin{tabular}{|l|c|c|}
\hline \multicolumn{1}{|c|}{ Країна } & Обсяг виробництва, млн гл. & Площа насаджень, тис. га \\
\hline \multicolumn{1}{|c|}{ Італія } & 2 & 3 \\
\hline Франція & 54,8 & 702 \\
\hline Іспанія & 49,1 & 789 \\
\hline США & 44,4 & 969 \\
\hline Аргентина & 23,9 & 430 \\
\hline Австралія & 14,5 & 219 \\
\hline Чилі & 12,9 & 145 \\
\hline Німеччина & 12,9 & 212 \\
\hline Південна Африка & 9,8 & 103 \\
\hline Китай & 9,5 & 125 \\
\hline Португалія & 9,3 & 875 \\
\hline Румунія & 6,1 & 192 \\
\hline Угорщина & 5,1 & 191 \\
\hline Бразилія & 3,6 & 69 \\
\hline Нова Зеландія & 3,1 & 82 \\
\hline
\end{tabular}


ФІНАНСОВІ РЕСУРСИ: ПРОБЛЕМИ ФОРМУВАННЯ ТА ВИКОРИСТАННЯ

Закінчення табл. 2

\begin{tabular}{|l|c|c|}
\hline \multicolumn{1}{|c|}{1} & 2 & 3 \\
\hline Австрія & 2,8 & 48 \\
\hline Греція & 2,2 & 106 \\
\hline Молдова & 1,9 & 147 \\
\hline Швейцарія & 1,1 & 15 \\
\hline Болгарія & 1,0 & 64 \\
\hline
\end{tabular}

Джерело: складено автором на основі джерела [17].

Світове виробництво вина збільшилось у 2018 році на 12 \% у порівнянні з 2017 роком, який став найгіршим для винної галузі за 20 років. Нині сукупний обсяг виробленого у світі вина збільшився приблизно на 4,1 млрд пляшок - 3251 млн до 282 млн гектолітрів. Попередній рік був дуже несприятливим для основних виробників вина Італії, Франції та Іспанії. Італія в 2018 році зберегла статус найбільшого виробника вин у світі, виготовивши 54,8 млн гектолітрів. Італія стала головним постачальником вина в Україну. У Франції винороби підвищили виробництво одразу на 27 \% - до 49,1 млн гектолітрів. В Іспанії відбувся підйом на $26 \%$ - до 44,4 млн гектолітрів. У США, які посідають четверте місце, очікується підвищення виробництва вина на $2 \%$ - до 23,9 млн гектолітрів. Зниження в порівнянні з 2017 роком відбулось у Португалії і Греції. Нагадаємо, в 2017 році українські винороби виробили 18,7 млн дал виноматеріалів, що майже на 2 млн дал більше, ніж роком раніше. При цьому переробили 270 тис. т винограду, 3 яких виростили самі тільки 42 тис. т, а решту 228 тис. т купили. У 2017 році різко збільшилося виробництво коньячних виноматеріалів. Якщо в 2016-му їх справили 2,1 млн дал., то минулого року майже вдвічі більше - 3,98 млн дал.

Скорочення темпів виробництва вина в багатьох країнах пов'язане 3 кліматичними умовами, змінами в політичній сфері, ослабленням підтримки цієї галузі на державному рівні та ін. Аргентина, Чилі, Китай, Великобританія, Індія і деякі африканські країни активно використовують ці тенденції для збільшення власних обсягів продажів на світовому ринку. Глобалізація ринку виноробства змусили виробників якомога більш оптимально використовувати площі, вибирати сорти, які дають найелегантніші й водночас багаті смаки, і вдумливо підходити до процесу виготовлення вина. Зміна клімату викликала поява холодного виноградарства в країнах, які вважалися для виноробства абсолютно не придатними.

Зниження темпів виробництва у виноробстві багатьох країн - потенційних конкурентів у цій сфері є сприятливим фактором для українського виноробства, що має позитивно змінюваний в сторону якості вин попит, а також значні невикористані можливості їх виробництва, але поки темпи виробництва вина в України знижуються. Зростаючий попит задовольняється в основному за рахунок імпорту в Україну виноградних вин переважно італійського, французького, іспанського й молдовського виробництва. Попит на якісну продукцію $є$ зростаючим, але незадоволеним.

Сучасний споживач чекає від вина легшого, фруктового смаку, і багато винороби, виконуючи його побажанням, мінімізують бочкову витримку або зовсім відмовляються від неї. Сьогодні здебільшого затребувані легкі сухі вина. Солодкі насичені вина не так популярні, а цінителі таких вин шукають у них або в прямому сенсі родзинку (багатьом любителям вин подобаються вина $з$ підв'яленого винограду), або якусь особливу вишуканість - так, вина з винограду з благородною гниллю та Айсвайн (крижані вина) мають попит і особливо цінуються гурманами. В Україні основними видами продукції, що випускається виноробної галуззю продукції (70-75 \% від загального обсягу вироблених вин) поки є столові напівсолодкі вина, виробництво яких здійснюється шляхом купажування цукровмісних речовин виноградного походження і сухих виноматеріалів. 
ФІНАНСОВІ РЕСУРСИ: ПРОБЛЕМИ ФОРМУВАННЯ ТА ВИКОРИСТАННЯ

Таким чином, продукції українських виробників для повноцінної конкуренції з імпортними винами не вистачає впізнаваності, іміджевих характеристик, різноманітності смаків, витримки, які й забезпечують у сучасних умовах переваги вибору.

Сприятливі умови для вирощування винограду, низька вартість робочої сили, сприятливе геополітичне положення зумовили увагу до цього регіону іноземних виробників, які викуповують землі на території області, організовують вирощування винограду та виробництво власного вина, зокрема на експорт, що посилює конкуренцію на цьому ринку і змушує українських виробників активно розвиватися.

За останні роки виноробні компанії серйозну увагу приділяли оновленню техніки та технологій, маркетингової та асортиментної політики, логістики, упаковці. Виробництво вина в абсолютній більшості виноробних країн орієнтоване на підвищення якості. В Одеській області вже сьогодні виробляються вина, якість яких не поступається кращим світовим зразкам. Розширюється асортимент пропозиції в бік збільшення частки марочних вин, розширення лінійок вироблених вин, купажу, появи нових марок. Однак поняття якості вина тісно пов'язане з якістю вирощуваного винограду. В Одеській області останнім часом проведена заміна сортів і технологій обробки землі і вирощування винограду, однак закладені плантації необхідну якість в повному обсязі починають забезпечувати вже в більш значно зрілому віці саджанців, так що основний потенціал розвитку компаній за рахунок якості поки тільки в майбутньому.

Тому ще сильні радянські традиції валового виробництва столового напівсолодкого вина. Велику частку займають ігристі вина. Інвестування в сферу виноградарства і виноробства не забезпечує швидкої окупності, вимагає «довгих» грошей, пов'язане 3 великими ризиками, насамперед погодними, може ефективно здійснюватися за підтримки цієї сфери з боку держави й місцевих крайових структур. Не сприяє активному розвитку українського виноробства відсутність власного виробництва в споріднених і підтримуючих галузях (виробництва техніки і обладнання, виробництва необхідних добрив і засобів обробки і догляду за грунтом і рослинами, виробництва пробок, пляшок, винних бочок ін.). В області представлені навчальні та науково-дослідні структури, що забезпечують підготовку фахівців і наукові розробки в області виноградарства і виноробства, які можна було б використовувати більш ефективно. $€$ всі підстави для формування на території області виноробного кластера за подобою квіткового кластера Нідерландів, що є лідером світового квіткового ринку. Оцінка стану українських виноробних малих та середніх підприємств представлена в табл. 3.

Таблиця 3

Сильні і слабкі сторони малих та середніх виноробних підприємств Одеського регіону

\begin{tabular}{|c|c|c|}
\hline Аспект діяльності & Сильні сторони & Слабкі сторони \\
\hline 1 & 2 & 3 \\
\hline $\begin{array}{l}\text { 1. Продукція та } \\
\text { виробництво }\end{array}$ & $\begin{array}{l}\text { 1. Сучасне обладнання і технології. } \\
\text { 2. Унікальність місцевих умов (географія, гео- } \\
\text { логія, клімат) і смакових якостей сировини. } \\
\text { 3. Власна сировинна база. } \\
\text { 4. Замкнутий цикл виробництва. } \\
\text { 5. Можливість виробляти продукцію на рів- } \\
\text { ні світових стандартів якості }\end{array}$ & $\begin{array}{l}\text { 1. Висока енергоємність виробництва. } \\
\text { 2. Слабке завантаження переробних } \\
\text { потужностей. } \\
\text { 3. Зростання тіньового обороту фа- } \\
\text { льсифікованої продукції. } \\
\text { 4. Недостатність «географічної про- } \\
\text { дукції» }\end{array}$ \\
\hline 2. Кадри & $\begin{array}{l}\text { 1. Найбільша кількість робочих місць з усіх } \\
\text { галузей сільського господарства. } \\
\text { 2. Висококваліфіковані досвідчені фахівці }\end{array}$ & $\begin{array}{l}\text { 1. Відсутність винної культури су- } \\
\text { часного вирощування та виробниц- } \\
\text { тва вина }\end{array}$ \\
\hline
\end{tabular}


Закінчення 3

\begin{tabular}{|c|c|c|}
\hline 1 & 2 & 3 \\
\hline 3. Маркетинг & $\begin{array}{l}\text { 1. Висока оцінка на міжнародних конкурсах. } \\
\text { 2. Розвиток дегустаційної діяльності (вин- } \\
\text { ний туризм). } \\
\text { 3. Широкий асортимент продукції. } \\
\text { 4. Самостійна діяльність по збуту своєї про- } \\
\text { дукції. } \\
\text { 5. Позитивний імідж підприємств }\end{array}$ & $\begin{array}{l}\text { 1. Нерозвиненість системи збуту } \\
\text { готової продукції. } \\
\text { 2. Слабка рекламна компанія. } \\
\text { 3. маловідомі продукції і компаній } \\
\text { на російському та світовому ринках, } \\
\text { відсутність прихильності покупців, } \\
\text { іміджу }\end{array}$ \\
\hline 4. Організація & $\begin{array}{l}\text { 1. Ручний збір винограду. } \\
\text { 2. Використання досвіду роботи іноземних } \\
\text { консультантів. } \\
\text { 3. Наявність підприємств } 3 \text { холдинговою } \\
\text { структурою }\end{array}$ & $\begin{array}{l}\text { 1. Низький рівень механізації і ку- } \\
\text { льтури обробки і добрива грунтів. } \\
\text { 2. Відсутність багатьох підтримую- } \\
\text { чих галузей (техніка та обладнання, } \\
\text { пробки, бочки, добрива та ін.) } \\
\text { 3. Імпортна залежність від постача- } \\
\text { льників }\end{array}$ \\
\hline 5. Фінанси & $\begin{array}{l}\text { 1. Інвестиційна привабливість. } \\
\text { 2. Власна бізнес-політика }\end{array}$ & $\begin{array}{l}\text { 1. Великі початкові вкладення. } \\
\text { 2. Необхідність «довгих» грошей }\end{array}$ \\
\hline 6. Інновації & 1. Нові унікальні проєкти & 1. Дорожнеча проєктів із модернізації \\
\hline
\end{tabular}

Джерело: складено автором.

Висновки і пропозиції. Таким чином, можна зазначити, що проведений критичний огляд поняття «конкурентоспроможність підприємства» дозволив виявити недоліки відомих визначень. Конкурентоспроможність малих і середніх підприємств можна визначити як здатність підприємницьких структур проявляти гнучкість, адаптивність до постійних змін зовнішнього середовища 3 метою збільшення, зменшення, або збереження займаної частки ринку залежно від стратегії підприємства.

Загалом на ринку виноградарства й виноробства Одеського регіону можна констатувати підвищення конкурентоспроможності діяльності малих та середніх підприємств виноградарської галузі. Водночас діяльність компаній великою мірою залежить від державної політики в цій сфері, що не повною мірою використовують можливості самих фірм у напрямі підвищення впізнаваності, підвищення купівельної прихильності й лояльності, розширення ринків збуту.

Важливо зазначити, що спостерігається підвищення конкурентоспроможності малих та середніх підприємств Одеського регіону на ринку виноградарства й виноробства. Виноробні підприємства регіону намагаються в основному виживати та розвиватися за рахунок лідерства у витратах, організації збуту продукції на місцевому ринку. Роль цінової конкуренції на цьому ринку велика, але на світовому ринку сьогодні затребувана різноманітність смаків, зумовлена географічним місцем зростання винограду.

В Одеській області для цього $є$ унікальні можливості, виноробні малі та середні підприємства перебудовують уже своє виробництво в цьому напрямі, але значна частина покупців про це просто не поінформована, проте деякі мають можливості для дегустації і формування своєї прихильності до подібної продукції. Затребувані на ринку самобутність і ексклюзивність при перевіреному рівні якості вина можна розглядати як основний напрям підвищення конкурентоспроможності малих та середніх підприємств Одеського регіону. Місцеві традиції виробництва, індивідуальні особливості регіону, національний колорит дозволяють забезпечити ефективну політику просування власної продукції.

Основним ключовим фактором успіху на цьому ринку є міжнародна вдячність i імідж малих та середніх підприємств як фактор споживчого вибору. Виноробні підприємства краю активно беруть участь у міжнародних виставках, посідаючи високі позиції і нагороди. Але цих зусиль недостатньо. 
ФІНАНСОВІ РЕСУРСИ: ПРОБЛЕМИ ФОРМУВАННЯ ТА ВИКОРИСТАННЯ

Найбільш поширений у світі виноградарсько-виноробний туризм, пов'язаний із відвідуванням географічних місць вирощування винограду та виробництва вина (виноградарських господарств, винотека, виноробних підприємств, виставкових і дегустаційних залів, сховищ вина, винних фестивалів, сільських свят, спеціалізованих ресторанів i магазинів) з метою дегустації і придбання виноробної продукції безпосередньо на місці зростання і виноробства, знайомства з природними, культурними, гастрономічними традиціями регіону, технологічними особливостями виноробства, поки як можливість розвитку використовується недостатньо, але може стати серйозним напрямом формування впізнаваності, споживчих переваг і лояльності до географічних вин Одеського регіону.

У зв'язку з цим різноманітні зусилля доступні малим та середнім підприємствам, але збільшити потенціал розвитку за рахунок цього напряму значною мірю можуть регіональна влада Одеського регіону, забезпечуючи інфраструктурну, інформаційну, рекламну підтримку, включивши це в стратегію розвитку регіону. Виноград, виноградний сік, виноградні кісточки у світі широко використовуються для лікування та спапроцедур. Цей напрям у поєднанні зі знайомством із місцевим способом життя, звичаями, оздоровчим проживанням у сільському середовищі, сприятливим кліматом також $\epsilon$ доступним і ефективним способом забезпечення реклами виноробства Одеського регіону. Відходами виноробного виробництва при повному циклі вважаються кісточки, макуха та інше. Усе це може бути використано як для збільшення обороту фірм через випуск додаткової лікувальної, косметичної продукції, харчових і кормових добавок, так і в як додаткова реклама і підвищення іміджу фірм.

Іншим напрямом, що сприяє підвищенню рівня конкурентоспроможності підприємств малого та середнього бізнесу виноробної галузі, може стати державна підтримка цієї сфери. Уся діяльність спрямована на припинення порушень в податковій сфері; боротьбу із сурогатами й фальсифікатами поганої якості, що заподіюють шкоду здоров'ю людини; вилучення з обігу продукції низької якості; тарифно-митну політику в частині обмеження ввезення імпортної продукції. Належна увага до цієї сфери діяльності, ефе-

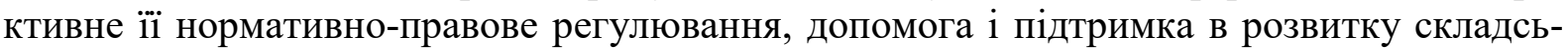
кої і транспортної інфраструктури, формування політики інвестування, кредитної політики, митно-тарифної політики просування української продукції, розвиток споріднених і підтримуючих галузей, допомога у формуванні виноробного кластера, що об'єднує зусилля всіх або більшості ланок створення цінності вина, могли б значною мірою сприяти збільшенню обсягів виробництва якісної продукції, імпортозаміщення, задоволенню попиту як на внутрішньому ринку, так збільшення експорту на світовий ринок.

\section{Список використаних джерел}

1. Вагін С. А. Тенденції розвитку корпоративного управління в світовій економіці. СанктПетербург: СПбГУЕФ, 2012. 181 с.

2. Воронов А. Міжнародна конкуренція в XXI столітті. Маркетинг за кордоном. 2009. № 2. C. $16-24$.

3. Грузинів В. П. Економіка підприємства. Москва: Фінанси і статистика, 2014. 208 с.

4. Державна служба статистики України: [вебсайт]. URL: http://www.ukrstat.gov.ua.

5. Дзахмішева И. Ш. Методика оцінка конкурентоспроможності послуги в роздрібній торговельній мережі. Маркетинг за кордоном. 2012. № 3. С. 40-48.

6. Калятін В. О., Наумов В. Б., Никифорова Т. С. Досвід Європи, США та Індії в сфері державної підтримки інновацій. Юридичний Журнал. 2011. Вип. 1, № 76. С. 8-9.

7. Лебедєва I. Тенденції науково-технічного розвитку малого бізнесу в Японії. Проблеми теорії і практики управління. 2017. Вип. 2, № 3. С. 33-35.

8. Лебедєва Л. США: держава і малий бізнес. Людина і праия. 2009. № 3. С. 13-14.

9. Малий бізнес по-японські. URL: https://www.openbusiness.ru/html_euro/Japan_open6.htm. 
ФІНАНСОВІ РЕСУРСИ: ПРОБЛЕМИ ФОРМУВАННЯ ТА ВИКОРИСТАННЯ

10. Попов М. В японському розрізі. Бізнес журнал. URL: http:/offline.busness-magazine.ru/ 2003/36/110572.

11. Про захист економічної конкуренції: Закон України від 11.01.2001 № 2210-III. URL: https://zakon.rada.gov.ua/laws/show/2210-14.

12. Про схвалення Стратегії розвитку малого і середнього підприємництва в Україні на період до 2020 року: Розпорядження Кабінету Міністрів України від 24.05.2017 р. № 504-p. URL: https://zakon.rada.gov.ua/laws/show/504-2017-\%D1\%80.

13. У Фінляндії $65 \%$ ВВП виробляє малий бізнес. Економіка.by. URL: http://www.ekonomika.by/?option=com_content\&catid=140\&id=17158\&view=article\&Itemid=273\& fontstyle=f-larger.

14. Comparison of Methods For Determining The Competitiveness of Enterprises To Determine MarketStrategy / S. Bondarenko and other. International Journal of Civil Engineering and Technology. 2018. Issue 13, № 9. P. 890-898.

15. Kalaman O., Okulicz-Kozaryn W., Purtskhvanidze O. Risk as a specific component of strategic enterprises management in the agrarian sector in the current conditions of Ukraine development. Food Industry Economics. 2019. Vol. 11, Issue 2. P. 54-61. DOI: 10.15673/fie.v11i2.1395.

16. Managing the Competitiveness of the Enterprise in the Context of Transformational Change / ‥ Kuprina та ін. International Journal of Recent Technology and Engineering. 2019. Вип. 2 , № 8. C. 4909-4914.

17. Wine-and-spirits.md: [вебсайт]. URL: https://wine-and-spirits.md/oiv-o-mirovom-proizvodstve-ipotreblenii-vina-v-2018-g.

\section{References}

1. Vahin, S. A. (2012). Tendentsii rozvytku korporatyvnoho upravlinnia v svitovii ekonomitsi [Trends in corporate governance in the global economy]. SPb: SPbHUEF [in Russian].

2. Voronov, A. (2009). Mizhnarodna konkurentsiia v XXI stolitti [International competition in the XXI century]. Marketynh za kordonom - Marketing abroad, 2, 16-24 [in Ukrainian].

3. Hruzyniv, V. P. (2014). Ekonomika pidpryiemstva [Economy of enterprise]. Moscow: Finansy i statystyka [in Russian].

4. Derzhavna sluzhba statystyky Ukrainy [State Statistics Service of Ukraine] (2020). Retrieved from http://www.ukrstat.gov.ua/.

5. Dzakhmisheva, Y. Sh. (2012). Metodyka otsinka konkurentospromozhnosti posluhy v rozdribnii torhovelnii merezhi [Methods of assessing the competitiveness of services in the retail trading network]. Marketynh za kordonom - Marketing abroad, 3, 40-48 [in Ukrainian].

6. Kaliatin, V. O., Naumov, V. B., Nykyforova, T. S. (2011). Dosvid Yevropy, SShA ta Indii v sferi derzhavnoi pidtrymky innovatsii [Experience of Europe, USA and India in the field of state support of innovations]. Yurydychnyi Zhurnal - Legal Journal, 76(1), 8-9 [in Ukrainian].

7. Lebedieva, I. (2017). Tendentsii naukovo-tekhnichnoho rozvytku maloho biznesu v Yaponii [Trends in the scientific and technical development of small business in Japan]. Problemy teorii $i$ praktyky upravlinnia - Problems of management theory and practice, 3 (2), 33-35 [in Ukrainian].

8. Lebedieva, L. (2009). SShA: derzhava i malyi biznes [United States: the state and small business]. Liudyna i pratsia - Man and work, 3, 13-14 [in Ukrainian].

9. Kharitonova, D. (n.d.). Malyi biznes po-yaponski [Small business in Japane]. www.openbusiness.ru. Retrieved from https://www.openbusiness.ru/html_euro/Japan_open6.htm.

10. Popov, M. (n.d.). V yaponskomu rozrizi [In the Japanese Section]. Biznes zhurnal-Business magazine. Retrieved from http: /offline.busness-magazine.ru/2003/36/110572.

11. Pro zakhyst ekonomichnoi konkurentsii [On Protection of Economic Competition] № 2210-III (11.01.2001) [in Ukrainian].

12. Pro skhvalennia Stratehii rozvytku maloho i serednoho pidpryiemnytstva v Ukraini na period do 2020 roku [On approval of the Strategy for the development of small and medium-sized enterprises in Ukraine for the period up to 2020]. № 504 (24.05.2017) [in Ukrainian]. 
ФІНАНСОВІ РЕСУРСИ: ПРОБЛЕМИ ФОРМУВАННЯ ТА ВИКОРИСТАННЯ

13. U Finliandii $65 \%$ VVP vyrobliaie malyi biznes [In Finland, 65\% of GDP is produced by small businesses]. Retrieved from http://www.ekonomika.by/?option=com content\&catid=140\&id= $17158 \&$ view $=$ article $\&$ Itemid $=273 \&$ fontstyle $=$-larger.

14. Bondarenko, S., Liganenko, I., Kalaman, O., \& Niekrasova, L. (2018) Comparison of Methods For Determining The Competitiveness of Enterprises To Determine MarketStrategy. International Journal of Civil Engineering and Technology, 13(9), 890-898 [in English].

15. Kalaman, O., Okulicz-Kozaryn, W. \& Purtskhvanidze, O. (2019). Risk as a specific component of strategic enterprises management in the agrarian sector in the current conditions of Ukraine development. Food Industry Economics, 11(2), 54-61. DOI: 10.15673/fie.v11i2.1395 [in English].

16. Kuprina, N., Stupnytska, T., Vaskovska, K., Boyko, O., Baraniuk, K. \& Markova, T. (2019). Managing the Competitiveness of the Enterprise in the Context of Transformational Change. International Journal of Recent Technology and Engineering, 8(2), 4909-4914. DOI: 10.35940/ijrte.B3706.078219.

17. Wine-and-spirits.md [Wine-and-spirits.md]. Retrieved from https://wine-and-spirits.md/oiv-omirovom-proizvodstve-i-potreblenii-vina-v-2018-g/.

Каламан Ольга Борисівна - кандидат економічних наук, доцент, доцент кафедри менеджменту і логістики, Одеська національна академія харчових технологій (вул. Канатна, 112, м. Одеса, 65039, Україна).

Каламан Ольга Борисовна - кандидат экономических наук, доцент, доцент кафедры менеджмента и логистики, докторант, Одесская национальная академия пищевых технологий (ул. Канатная, 112, г. Одесса, 65039, Украина).

Kalaman Olga - PhD in Economics, Associate Professor, Associate Professor, Department of Management and Logistics, doctoral student, Odessa National Academy of Food Technologies (112 Kanatna Str., 65039 Odessa, Ukraine).

E-mail: kalaman.olga@gmail.com

ORCID: https://orcid.org/0000-0001-5586-7654

ResearcherID: B-2755-2019

Scopus Author ID: 57205329026 